\title{
Onkohematológiai betegek véráram- infekcióinak epidemiológiája és prognózisa napjainkban: egy hazai centrum adatainak retrospektív elemzése
}

\author{
Péli Dorina ${ }^{1 @}$, Nikolova Radka ${ }^{2}$, Reményi Péter ${ }^{3}$, Sinkó János ${ }^{3}$ \\ 'Általános Orvostudományi Kar, Semmelweis Egyetem, Budapest \\ ${ }^{2}$ Mikrobiológiai Laboratórium, Semmelweis Egyetem, Budapest \\ ${ }^{3}$ Hematológiai és Őssejt-transzplantációs Osztály, \\ Egyesített Szt. István és Szt. László Kórház Rendelőintézet \\ (jelenleg Dél-pesti Centrumkórház - Országos Hematológiai és Infektológiai Intézet)
}

\begin{abstract}
Bevezetés: Hematológiai és őssejt-transzplantált betegek véráram-infekcióiról kevés adat áll rendelkezésre. Epidemiológiájuk naprakész ismerete ugyanakkor elengedhetetlen a hatékony terápia megválasztásához. Célkitüzés: Jelen kutatás célja a véráram-infekciók gyakoriságának, a kórokozók megoszlásának és rezisztenciájának elemzése, a 7 és 30 napos halálozás, illetve az ezt befolyásoló rizikófaktorok vizsgálata volt. Módszer: 2016. január és 2017. július között a Hematológiai és Őssejt-transzplantációs Osztályon ápolt betegek véráram-infekcióira vonatkozó adatok kerültek feldolgozásra. Az adatokat, az intézményi adatbázisokból gyűjtöttük össze és retrospektív módon elemeztük, leíró statisztikai módszerek alkalmazásával. A rezisztenciára vonatkozó adatokat összevetettük az Országos Epidemiológiai Központ 2016-os adataival. Eredmények: Összesen 362 beteg 624 pozitív vérmintájából 216 kontaminációnak bizonyult. A 408 nem kontamináns izolátumhoz kapcsolódó epizódok száma 353 volt. A monomikrobás $(N=320)$ epizódok hátterében 149 (47\%) esetben Gram-pozitív, 166 (52\%) esetben Gram-negatív, 5-ben (2\%) pedig gomba kórokozó igazolódott. Gram-pozitív speciesek: koaguláz-negatív staphylococcusok (49\%), Staphylococcus aureus (16\%), Streptococcus species (15\%). Gram-negatív speciesek: Escherichia coli (46\%), Klebsiella species (19\%) és Pseudomonas aeruginosa (17\%). A Staphylococcus aureusok 19\%-a, a Staphylococcus epidermidis törzsek 73\%-a methicillinrezisztens, az enterococcusok 20\%-a vancomycinrezisztens, az Acinetobacter baumannii és Pseudomonas aeruginosa törzsek $40 \%$ illetve 11\%-a multirezisztens, a Gram-negatívok 27\%-a fluorokinolonrezisztens, az Enterobacteriales $14 \%$-a kiterjedt spektrumú béta-laktamáz-termelő volt. A 7 és 30 napos halálozás $12 \%$ és $21 \%$ volt. Halálozás szempontjából szignifikánsan magasabb kockázatot jelentett a fungaemia $(p=0,007)$ és a myeloma multiplex mint alapbetegség $(p=0,045)$. Következtetések: Kutatásunkban a Gram-negatív baktériumok enyhe túlsúlyát és az országos átlagnál kedvezőbb rezisztenciát figyeltünk meg. Halálozás szempontjából kiemelt figyelmet érdemelnek a myeloma multiplexes betegek és a gombainfekciók.
\end{abstract}

Kulcsszavak: véráramfertőzés, bacteriaemia, hematológia, antibiotikum-rezisztencia

\section{Actual epidemiology and prognosis of bloodstream infections in oncohematology patients: retrospective analysis of data from a Hungarian centre}

\begin{abstract}
Introduction: Recently, only few data on bloodstream infections in hematology patients have been published. For appropriate antimicrobial management, knowledge in current epidemiology is inevitable. Aim: Present study aimed at assessing incidence of bacteremia, type and resistance of pathogens, as well as 7- and 30-day mortality with relevant risk factors. Methods: Cases of bacteremia treated at the hematology center between January 2016 and July 2017 were included. Data collected from institutional databases were retrospectively analyzed using descriptive statistics. Antimicrobial resistance has been compared with National Center for Epidemiology data. Results: There were 624 positive blood samples from 362 patients, of which 216 were contaminations. The number of episodes related to non-contaminant pathogens was 353. Among 320 monomicrobial episodes, 149 were Gram-positive, 166 Gram-negative bacteremias and 5 were fungemias. Gram-positive isolates: coagulase-negative staphylococci (49\%), Staphylococcus aureus (16\%), Streptococcus species (15\%). Gram-negative isolates: Escherichia coli (46\%), Klebsiella species (19\%), Pseudomonas aeruginosa
\end{abstract}

@ Levelezési cím: Dr. Péli Dorina, Pest Megyei Flór Ferenc Kórház, Kistarcsa, Semmelweis tér 1.;

Tel.: +36-20-260 6694, E-mail: peli.dorina@gmail.com 
(17\%). Rate of antibiotic-resistance: 19\% methicillin-resistance in Staphylococcus aureus, $73 \%$ methicillin-resistance in Staphylococcus epidermidis, $20 \%$ vancomycin-resistance in enterococci. Forty per cent of Acinetobacter baumannii, and $11 \%$ of Pseudomonas aeruginosa were multiresistant. Twenty-seven per cent of Gram-negative bacteria were fluoroquinolon-resistant and $14 \%$ of Enterobacteriales produced extended spectrum beta-lactamases. Mortality at day 7 and 30 was $12 \%$ and $21 \%$, respectively. Higher risk of mortality was seen in fungemia $(p=0.007)$ and in multiple myeloma patients $(p=0.045)$. Conclusion: Present study confirmed predominance of Gram-negative bacteremias together with lower resistance compared to national average. Potentially fatal infections warrant attention in patients with multiple myeloma and in fungemia.

Keywords: blood culture, multidrug-resistant bacteria, microbial drug resistance

(Beérkezett: 2019. január 30.; elfogadva: 2019. március 4.)

\section{Rövidítések}

ALL = akut lymphoblastos leukemia; AML = akut myeloid leukemia; $\mathrm{ANC}=$ abszolút neutrophilszám; CLL = krónikus lymphoid leukemia; CNS = koaguláz-negatív Staphylococcus; ECDC = European Centre for Disease Prevention and Control; ESBL = kiterjedt spektrumú béta-laktamáz; FQRGN = fluorokinolonrezisztens Gram-negatív baktérium; GVHD = graft- versus hostbetegség; HL = Hodgkin-lymphoma; HSCT = hemopoetikus össejt-transzplantáció; MACI = multirezisztens Acinetobacter baumannii $; \mathrm{MM}=$ myeloma multiplex $; \mathrm{MPAE}=$ multirezisztens Pseudomonas aeruginosa $;$ MRSA = meticillinrezisztens Staphy lococcus aureus; MRSE = meticillinrezisztens Staphylococcus epidermidis; NHL = non-Hodgkin-lymphoma; VRE = vancomycinrezisztens Enterococcus faecium

Hematológiai és őssejt-transzplantált betegek körében a véráram-infekciók gyakori (11-38\%) és magas halálozással járó (18-42\%) megbetegedések [1]. Ennek okai között számos rizikótényező szerepe feltételezhető. Ilyen többek között maga a malignus alapbetegség, a kezelés következtében kialakuló mucositis és neutropenia, intravaszkuláris eszközök használata, illetve a hemopoetikus őssejt-transzplantáció [2-4]. Fontos továbbá, hogy világszerte növekedő tendenciát mutat a rezisztens kórokozók előfordulási aránya, a következményes fertőzések pedig tovább rontják az érintettek túlélési esélyeit [5]. Mindezek ellenére viszonylag kevés adat áll rendelkezésre e fertőzések epidemiológiáját illetően. Ezek ismerete ugyanakkor elengedhetetlen lenne a hatékony antimikrobás kezelés megválasztásához. Kutatásunk célja így az volt, hogy felmérjük a centrumban ápolt betegek körében a véráraminfekciók aktuális gyakoriságát, a kórokozók megoszlását és rezisztenciáját, valamint a 7 és 30 napos letalitást. Vizsgáltuk emellett a fatális kimenetelhez vezető rizikófaktorok szerepét is.

\section{Anyag és módszer}

Kutatásunkba az Egyesített Szt. István és Szt. László Kórház (jelenleg Dél-pesti Centrumkórház - Országos Hematológiai és Infektológiai Intézet) Hematológiai és Össejt- transzplantációs Osztályán a 2016. január és 2017. július között ápolt betegek kerültek bevonásra. Körükben a hemokultúra-pozitív, azaz mikrobiológiailag dokumentált véráram-infekciókat vizsgáltuk. A mikrobiológiai adatokat a kórház Mikrobiológiai Laboratóriuma szolgáltatta, amely tartalmazta az izolált specieseket és azok in vitro rezisztencia adatait. A betegekre vonatkozó klinikai adatokat a Medsol adatbázisából gyűjtöttük össze. Utóbbi magában foglalta a hematológiai alapbetegség diagnózisát, az esetleges őssejt-transzplantáció típusát (allogén, autológ), a hemokultúra vételének napján mért abszolút neutrophilszámot (ANC), valamint azt, hogy a beteg életben volt-e az ezt követő 7. illetve 30. napon. Neutropéniásnak tekintettük a vizsgált személyt, ha ANC-értéke $<0,5 \mathrm{G} / 1$ volt. Az adatokat Excel táblázatban összesítettük, majd meghatároztuk az epizódok számát. Egy epizódhoz tartozónak a 3 napon belüli, pozitív hemokultúrákat vettük. Polimikrobás volt az az epizód, amelyben egy palack kettő vagy több speciest tartalmazott, vagy különböző kórokozót tartalmazó palackok voltak egy epizódon belül. Kontaminációnak tekintettük azokat az izolátumokat, amelyeknél a normál bőrflóra részét képező species (pl. koaguláz-negatív Staphylococcus [CNS], Micrococcus spp., Corynebacterium spp.) csak egy palackból tenyészett. Ezeket az epizódokat a további adatelemzésből kihagytuk. A többi izolátumot egyetlen pozitív hemokultúra esetén is kórokozónak tekintettük. Az adatgyüjtés retrospektív módon történt. A rezisztenciaadatokat az Országos Epidemiológiai Központ (OEK) honlapján található, 2016-os hazai adatokkal hasonlítottuk össze (invazív mintákból származó törzsek). Multirezisztens Pseudomonas aeruginosa (MPAE) esetén a European Centre for Disease Prevention and Control (ECDC) által közzétett adatokat vettük figyelembe, mivel az OEK rezisztenciaadatai csak az egyes antibiotikumokra vonatkoztak, a multirezisztenciáról nem szerepelt információ. $\mathrm{Az}$ adatok elemzése leíró statisztikai módszerekkel történt. A túlélés vizsgálatához a Fisher-féle egzakt tesztet és a logisztikusregresszió-analízist használtuk fel. A beavatkozással nem járó, retrospektív kutatás az Intézményi Etikai Bizottságnál bejelentésre került. 


\section{Eredmények}

Kutatásunkban 362 beteg (196 férfi, 166 nő) véráraminfekcióinak adatait elemeztük. A betegek medián életkora 59 (19-92) év volt. Alapbetegségüket tekintve 98 fó (27\%) AML-ben, 70 (19\%) non-Hodgkin-lymphomában (NHL), 67 (18\%) myeloma multiplexben (MM), 44 (12\%) akut lymphoblastos leukaemiában (ALL), 28 (8\%) CLL-ben, 20 (5\%) myelodysplasiás szindrómában (MDS), 14 (4\%) Hodgkin-lymphomában (HL), 23 (7\%) pedig egyéb hematológiai betegségben szenvedett. Hetven személy (19\%) allogén, 48 (13\%) autológ őssejt-átültetésben részesült (1. táblázat).

1. táblázat. Váráram-infekcióban szenvedő hematológiai betegek demográfiai adatai

\begin{tabular}{lc}
\hline Betegek száma & 362 \\
\hline Életkor (medián) & $59(19-92)$ \\
\hline Nem & \\
\hline Férfi & $196(54 \%)$ \\
Nő & $166(46 \%)$ \\
\hline Diagnózis & \\
\hline Akut myeloid leukemia & $98(27 \%)$ \\
Non-Hodgkin-lymphoma & $70(19 \%)$ \\
Myeloma multiplex & $67(18 \%)$ \\
Akut lymphoid leukemia & $44(12 \%)$ \\
Krónikus lymphoid leukemia & $28(8 \%)$ \\
Myelodysplasiás szindróma & $20(5 \%)$ \\
Hodgkin-kór & $14(4 \%)$ \\
Egyéb & $23(7 \%)$ \\
\hline Transzplantációs státusz & \\
\hline Allogén & $70(19 \%)$ \\
Autológ & $48(13 \%)$ \\
Nem transzplantált & $247(68 \%)$ \\
\hline
\end{tabular}

2. táblázat. Az izolátumok és a véráram-infekciós epizódok megoszlása

\begin{tabular}{lrc}
\hline & $N$ & $\%$ \\
\hline Izolátumok száma & 624 & \\
Valószínúleg kontamináns izolátumok & 216 & 35 \\
száma & & \\
Valószínúleg nem kontamináns izolátu- & 408 & 65 \\
mok száma & 353 & \\
\hline Nem kontamináns epizódok száma & 33 & 9 \\
Polimikrobás epizód & 320 & 91 \\
Monomikrobás epizód & 149 & 47 \\
- Gram-pozitív & 166 & 52 \\
- Gram-negatív & 5 & 2 \\
- Gomba & 211 & 60 \\
\hline Neutropeniás epizódok száma & 142 & 40 \\
Nem neutropeniás epizódok száma & &
\end{tabular}

A vérmintákból összesen 624 mikroba tenyészett ki, melyből 216 (35\%) kontamináns, 408 (65\%) nem kontamináns izolátumnak bizonyult. A nem kontamináns izolátumokhoz kapcsolódó epizódok száma 353 volt. Ezen belül 33 (9\%) polimikrobás, 320 (91\%) pedig monomikrobás epizód volt. A monomikrobás epizódokon belül 149 (47\%) esetben Gram-pozitív, 166 (52\%) esetben Gram-negatív, 5-ben (2\%) pedig gomba volt a kórokozó. A véráram-infekció 211 esetben (60\%) neutropéniás, 142 esetben (40\%) nem neutropéniás betegben lépett fel (2. táblázat).

A leggyakoribb Gram-pozitív speciesek a következő arányban fordultak elő: CNS 73 (49\%), Staphylococcus aureus 24 (16\%), Streptococcus spp. 22 (15\%), Enterococcus spp. 8 (5\%) (1. ábra). A Gram-negatív törzsek megoszlása: Escherichia coli 76 (46\%), Klebsiella spp. 31 (19\%), Pseudomonas aeruginosa 28 (17\%), Stenotrophomonas maltophilia 10 (6\%) (2. ábra). A fungaemiák hátterében 3 esetben Candida spp., 1-1-ben pedig Cryptococcus neoformans, illetve Fusarium spp. igazolódott. A polimikrobás infekciókon belül a kórokozók százalékos megosz-

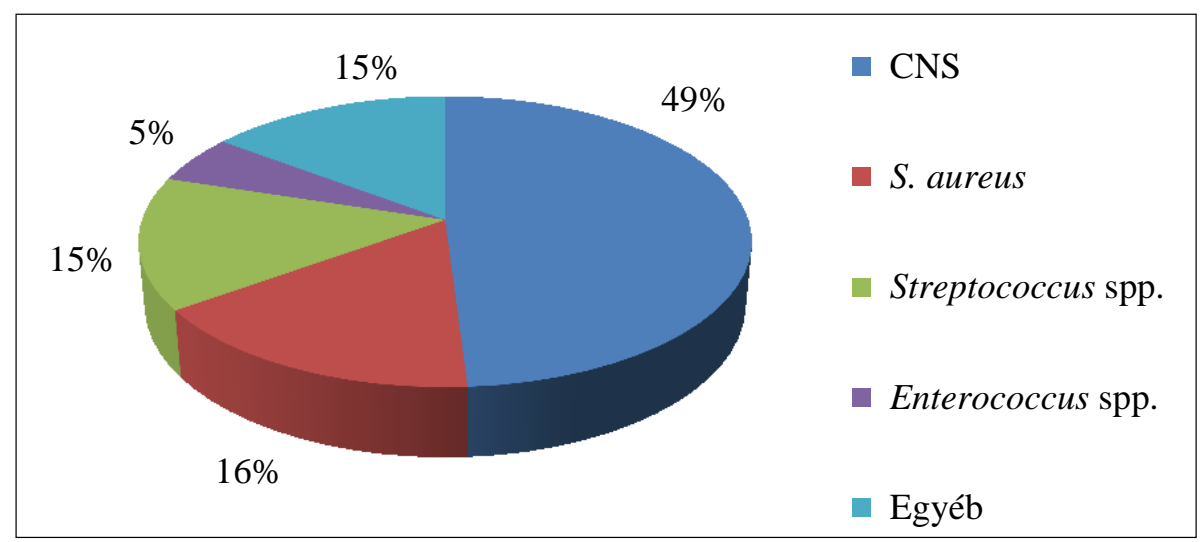

1. ábra. Gram-pozitív speciesek megoszlása. CNS: koaguláz-negatív Staphylococcus 


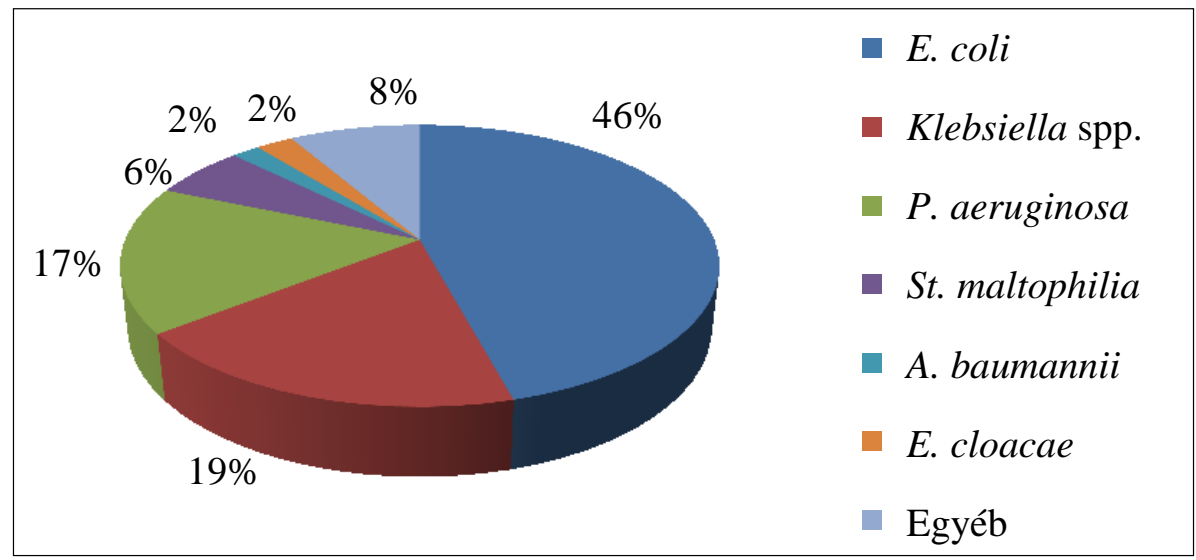

2. ábra. Gram-negatív speciesek megoszlása

lása: CNS 33\%, Staphylococcus aureus 9\%, Streptococcus spp. $21 \%$ és Enterococcus spp. $21 \%$, Escherichia coli $30 \%$, Klebsiella spp. $15 \%$ és Pseudomonas aeruginosa $21 \%$. A polimikrobás epizódok közül 8-at csak Gram-negatív, 12-t csak Gram-pozitív, 13-at pedig együttesen Gram-pozitív és Gram-negatív baktériumok okoztak.

Az antibiotikum-rezisztens törzsek előfordulási aránya: a Staphylococcus aureus törzsek 19\%-a bizonyult meticillinrezisztensnek (meticillinrezisztens Staphylococcus aureus [MRSA]). Ez az arány Staphylococcus epidermidisben már 73\%-nak adódott (meticillinrezisztens Staphylococcus epidermidis [MRSE]). Az Enterococcus faeciumizolátumok 20\%-ában igazolódott vancomycinrezisztencia (vancomycinrezisztens Enterococcus faecium [VRE]). A multirezisztencia kritériumainak (imipenem- és/vagy meropenemrezisztencia) az Acinetobacter baumannii törzsek 40\%-a felelt meg (multirezisztens Acinetobacter baumannii [MACI]). Pseudomonas aeruginosa esetében a multirezisztencia (piperacillin/tazobactam, ceftazidim, fluorokinolonok, aminoglikozidok és karbapenemek közül legalább hárommal szembeni rezisztencia) aránya $11 \%$ volt (MPAE). A Gram-negatív speciesek 27\%-a fluorokinolonrezisztens, az Enterobacteriales 14\%-a kiterjedt spektrumú béta-laktamáz- (ESBL-) termelő volt (3. táblázat).

A túlélés számításához 335 esetben állt rendelkezésre 30 napos követési adat. A 7 napos összhalálozás $12 \%$, a 30 napos 21\%-os volt. A Gram-pozitív és Gram-negatív kórokozók, neutropenia, életkor és transzplantációs státusz szerinti halálozási adatokat a 4. táblázat tartalmazza. Szignifikáns különbség volt a 65 év feletti és alatti életkorú betegek 7 napos $(p=0,0059)$ és 30 napos $(p=0,0178)$ halálozásában, valamint a nem transzplantált és transzplantált betegek 7 napos $(p=0,0468)$ halálozásában. Többváltozós adatelemzésben a gomba eredetü véráramfertőzések $(p=0,007) 7$ napos letalitása volt szignifikánsan magasabb. A többi alapbetegséghez képest a myeloma multiplexben szenvedők halálozási rátája szintén kedvezőtlenül alakult ( $p=0,045)$ függetlenül az életkortól, a transzplantációs státusztól és a neutropeniától.

\section{Megbeszélés}

A jelen kutatás célja a Hematológiai és Össejt-transzplantációs Osztályon ápolt betegek véráram-infekcióinak

3. táblázat. Antibiotikum-rezisztens törzsek aránya az országos átlaghoz viszonyítva

\begin{tabular}{lrlcc}
\hline & $N$ & Rezisztencia & $N(\%)$ & Országos (\%) \\
\hline S. aureus & 27 & MRSA & $5(19 \%)$ & 25,5 \\
S. epidermidis & 55 & MRSE & $40(73 \%)$ & 66 \\
Enterococcus spp. & 15 & VRE & $3 / 15$ & 23 \\
A. baumannii & 5 & MACI & $2 / 5$ & $72-74^{*}$ \\
P. aeruginosa & 35 & MPAE & $4(11 \%)$ & 19 \\
Gram-negatív & 187 & FQRGN & $50(27 \%)$ & $27-35^{* *}$ \\
Enterobacteriales & 133 & ESBL & $19(14 \%)$ & $16,5-37^{* *}$ \\
\hline
\end{tabular}

\footnotetext{
*imipenem-, meropenemrezisztencia; ** Escherichia coli, Klebsiella pneumoniae MRSA = meticillinrezisztens Staphylococcus aureus; MRSE = meticillinrezisztens Staphylococcus epidermidis; VRE = vancomycinrezisztens Enterococcus faecium; MACI = multirezisztens Acinetobacter baumannii; $\mathrm{MPAE}=$ multirezisztens Pseudomonas aeruginosa; FQRGN = fluorokinolonrezisztens Gram-negatív baktérium; ESBL = kiterjedt spektrumú béta-laktamáz-termelő species
} 
4. táblázat. 7 és 30 napos halálozási adatok epizódok szerint

\begin{tabular}{lcc}
\hline & 7 napos halálozás (\%) & 30 napos halálozás (\%) \\
\hline Gram-pozitív epizódok & 11 & 20 \\
Gram-negatív epizódok & 12 & 19 \\
Neutropeniás epizódok & 11 & 20 \\
Nem neutropeniás epizódok & 13 & 22 \\
65 év felettiek & 21 & $31^{*}$ \\
65 év alattiak & 9 & $18^{*}$ \\
Transzplantáltak & 7 & $15^{* *}$ \\
Nem transzplantáltak & 14 & $23^{* *}$ \\
Allogén HSCT & 7 & 16 \\
Autológ HSCT & 7 & 13 \\
\hline Összesen & 12 & 21 \\
\hline${ }^{*} p=0,0059 ; * p=0,0468$ & &
\end{tabular}

vizsgálata volt. A demográfiai adatok mellett a kórokozók megoszlását, antibiotikumokkal szembeni rezisztenciáját, valamint a 7 és 30 napos halálozási adatokat és azok rizikófaktorait elemeztük. Ezek az adatok információkkal szolgálhatnak a hazai epidemiológiai helyzetet illetően.

A leggyakoribb alapbetegségek közé az akut leukémiák, NHL és a myeloma multiplex tartoztak. Az izolátumok több mint $1 / 3$ része kontaminációnak bizonyult, ami rávilágít a szakszerü hemokultúra-vételi technika jelentőségére. Mivel a normál bőrflóra tagjai egyaránt lehetnek kórokozók és kontaminánsok is, fontos a pozitív minták megfelelő értékelése. Ennek egyik módja a pozitív palackok számarányának meghatározása. Ha a baktérium kettő vagy több palackból tenyészett ki, nagyobb eséllyel tekinthető patogénnek. A legtöbb tanulmány is ezt a gondolatmenetet követi. Az olyan vizsgálatokban, amelyekben az infekció forrása is szerepel, az egyidejü bőr-, lágyrész- vagy kanüleredetű fertőzés esetén egy pozitív hemokultúra is elengedő lehet [6]. A jelen kutatásban, annak retrospektív jellege miatt, ezt a tényezőt nem volt mód figyelembe venni.

A Gram-pozitív és Gram-negatív epizódok aránya $47 \%$ és $52 \%$ volt, ami jól korrelál az elmúlt évek során megfigyelhető jelenséggel, vagyis hogy a Gram-negatív bacteriaemiák aránya növekvő tendenciát mutat. Az 1990-es években még a Gram-pozitív baktériumok alkották a fertőzések 60-80\%-át, azonban a 2000-es évektől egyre inkább a Gram-negatívok kezdtek elötérbe kerülni [7]. Ennek hátterében elsősorban a fluorokinolonprofilaxis visszaszorulása állhat, feltehetően a rezisztenciától való félelem és a túlélésre gyakorolt hatás kétségessége miatt. Nagyon hasonló eredmények születtek egy 2014-ben publikált olasz kutatásban is, ahol a Gram-pozitív/Gramnegatív arány $46,6 \%$ és $52,8 \%$ volt [8]. Több olyan tanulmány is ismert, amelyben ennél sokkal nagyobb arányban fordultak elő a Gram-negatív kórokozók [9, 10] A hazai adatok közül a Szegedi Tudományegyetem által végzett kutatásban az összes izolátumnak 67,1\%-a Gram-pozitív baktérium volt, azonban ez a felmérés nem tért ki a potenciálisan kontamináns izolátumok arányára [6].

A speciesek megoszlási aránya hasonló volt a legtöbb korábbi európai kutatásban tapasztaltakhoz $[6,8,11,12]$. Az irodalmi adatokkal összevetve eredményeinkből kiemelendő az Enterobacter spp. és az Enterococcus spp. alacsonyabb, valamint a Staphylococcus aureus magasabb előfordulási aránya. A fungaemiák a véráramfertőzéseknek összesen 2\%-át képviselték. Korábbi publikációkban ez az arány 0,8-3,4\% között mozgott, és a speciesek közül szintén a Candida spp. fordult elő leggyakrabban $[6,13,14]$.

Az OEK és ECDC adatait alapul véve a legtöbb species esetén az országos átlagnál kedvezőbb rezisztenciaarányok mutatkoztak (3. táblázat). Bár a különböző módon gyűjtött adatok összevetése során óvatosan kell eljárni, lehetséges, hogy a rutinszerü fluorokinolonprofilaxis mellőzése kedvező hatással van a rezisztencia alakulására.

A 7 és 30 napos összhalálozás $12 \%$ és $21 \%$ volt. A publikált irodalomban $12 \%$ és $42 \%$ között találunk adatokat a véráram-infekciók halálozását illetően, azonban nem egységes, hogy az infekciót követő hányadik napon határozzák ezt meg. Egy 2009-ben publikált olasz kutatásban a hematológiai betegek véráram-infekcióinak 30 napos halálozása 20,3\% [15]. Szintén Olaszországban, egy allogén hemopoetikus őssejt-transzplantációval (HSCT) kezelt betegek körében végzett tanulmány szerint a 7 és 30 napos letalitás 15\%, illetve 27\%-nak adódott [14]. Találkozhatunk azonban ennél jóval kedvezőbb halálozási adatokkal is. Egy koreai, 2012-ben közreadott kutatás a 7 és 30 napos halálozás arányát 4,5\%, illetve 13,1\%-nak találta [13]. Ausztráliában, 2017-ben közzétett adatok szerint a 30 napon belül elhunytak aránya mindössze 5,9\% volt. 
Az utóbbiból kiemelendő, hogy az antibiotikum-rezisztencia mértékét is rendkívül alacsonynak találták [16].

A jelen vizsgálatban a gomba eredetű véráramfertőzések letalitása volt szignifikánsan a legmagasabb. A korábban említett olasz kutatás során hasonló következtetésre jutottak [14]. A fungaemiák alacsony száma miatt $(N=$ 5) természetesen hosszabb távú megfigyelés lenne szükséges a halálozási ráta pontos meghatározásához. A Candida spp. által okozott véráram-infekciót mint a halálozás egyik független rizikófaktorát azonban már 1987-ben leírták [17].

A 65 év feletti csoportban általunk megfigyelt magasabb letalitás a gyakori társbetegségek miatt nem meglepő eredmény.

Ezzel szemben nehezen értelmezhető, hogy az őssejttranszplantációban részesült betegek halálozása miért volt szignifikánsan alacsonyabb a nem transzplantált betegekéhez képest. A szokatlan jelenség hátterében feltételezhető, hogy a nagyrészt remisszióban lévő, HSCT-ra alkalmas, fit betegcsoport összességében kevesebb kockázati tényezővel terhelt, a részben terápiarezisztens, illetve relabáló, malignus hematológiai betegségben szenvedő, általános betegkörhöz képest. Ezen felül a nem transzplantáltak magasabb átlagéletkora is nagy valószínúséggel szerepet játszik a megnövekedett halálozásban.

A myeloma multiplexben szenvedő betegek szignifikánsan magasabb kockázattal rendelkeztek a halálozás szempontjából, függetlenül az életkortól, neutropéniától és a transzplantációs státusztól. A közelmúltban több jelentős változás következett be a myeloma multiplexterápiás lehetőségeinek terén, melynek eredményeként a kórkép számos vonalban, hosszú ideig kezelhető. Ugyanakkor az ismételten relabáló immunrendszeri malignitás és az ennek folytán egyre fokozódó immunszuppresszió egyre nagyobb infekciós kockázatot is eredményez. Ezen felül az infekciók profilaxisára és korai kezelésére kevesebb jól kidolgozott protokoll áll rendelkezésre, mint például akut leukémiák esetén [18].

A véráram-infekciók halálozását, a kórokozók spektrumát és az antibiotikum-rezisztencia alakulását fontos tehát figyelemmel kísérnünk, a minél hatékonyabb empirikus antibiotikum-választás érdekében. Különösen a fungaemiákra és a myeloma multiplexben szenvedő betegek súlyos infekcióra kell kiemelt figyelmet fordítanunk.

Nyilatkozat: Jelen kézirat eredeti mü, egyéb folyóiratban közlésre nem került. A szerzői útmutatót a levelező szerző elolvasta.

Anyagi támogatás: A szerzők a munkáért anyagi támogatásban nem részesültek.

Érdekeltségek: A szerzők a közlemény megírásáért támogatásban nem részesültek, érdekütközés nincs.

Szerzői munkamegosztás: P. D.: adatgyüjtés, elemzés, szövegezés, ábrák és táblázatok készítése. N. R.: mikrobiológiai adatok szolgáltatása, interpretálása. R. P.: Klinikai hematológiai adatok és összefüggéseik értékelése. S. J.:
Klinikai infektológiai adatok értékelése, összefüggésük vizsgálata a mikrobiológiai leletekkel. A kéziratot valamennyi szerző elolvasta és jóváhagyta. A szerzők köszönetüket fejezik ki dr. Szabó Bálint Gergelynek a nyújtott szakmai segítségért.

\section{Irodalom}

[1] Wisplinghoff $\mathrm{H}$, Seifert $\mathrm{H}$, Wenzel RP, et al. Current trends in the epidemiology of nosocomial bloodstream infections in patients with hematological malignancies and solid neoplasms in hospitals in the United States. Clin Infect Dis. 2003; 36: 1103-1110.

[2] Glauser MP, Calandra T. Infections in patients with hematologic malignancies. In: Glauser MP, Pizzo PA. (eds.) Management of Infections in Immunocompromised Patients. W. B. Saunders Company, Ltd., 2000; pp. 141-188.

[3] Niscola P, Romani C, Cupelli L, et al. Mucositis in patients with hematologic malignancies: an overview. Haematologica 2007; 92: 222-231.

[4] Tsai HC, Huang LM, Chang LY, et al. Central venous catheter-associated bloodstream infections in pediatric hematology-oncology patients and effectiveness of antimicrobial lock therapy. J Microbiol Immunol Infect. 2015; 48: 639-646.

[5] Kang CI, Kim SH, Park WB, et al. Bloodstream infections caused by antibiotic-resistant Gram-negative bacilli: risk factors for mortality and impact of inappropriate initial antimicrobial therapy on outcome. Antimicrob Agents Chemother. 2005; 49: 760766.

[6] Piukovics K, Terhes G, Lázás A, et al. Evaluation of bloodstream infections during chemotherapy-induced febrile neutropenia in patients with malignant hematological diseases: Single center experience. Eur J Microbiol Immunol (Bp). 2015; 5: 199-204.

[7] Menzo SL, la Martire G, Ceccarelli G, et al. New insight on epidemiology and management of bacterial bloodstream infection in patients with hematological malignancies. Mediterr J Hematol Infect Dis. 2015; 7: e2015044.

[8] Trecarichi EM, Pagano L, Candoni A, et al. Current epidemiology and antimicrobial resistance data for bacterial bloodstream infections in patients with hematologic malignancies: an Italian multicentre prospective survey. Clin Microbiol Infect. 2015; 21: 337343.

[9] Bousquet A, Malfuson JV, Sanmartin N, et al. An 8-year survey of strains identified in blood cultures in a clinical haematology unit. Clin Microbiol Infect. 2014; 20: O7-12.

[10] Gedik H, Simşek F, Kantürk A, et al. Bloodstream infections in patients with hematological malignancies: which is more fatal cancer or resistant pathogens? Ther Clin Risk Manag. 2014; 10: 743-752.

[11] Kjellander C, Björkholm M, Källman O, et al. Bloodstream infections in patients with chronic lymphocytic leukemia: a longitudinal single-center study. Ann Hematol. 2016; 95: 871-879.

[12] Syrjälä H, Ohtonen P, Kinnunen U, et al. Bloodstream infections during chemotherapy-induced neutropenia in adult patients with acute myeloid leukemia: treatment cycle matters. Eur J Clin Microbiol Infect Dis. 2010; 29: 1211-1218.

[13] Kwon JC, Kim SH, Choi JK, et al. Epidemiology and clinical features of bloodstream infections in hematology wards: one year experience at the catholic blood and marrow transplantation center. Infect Chemother. 2013; 45: 51-61.

[14] Mikulska M, Del Bono V, Bruzzi P, et al. Mortality after bloodstream infections in allogeneic haematopoietic stem cell transplant (HSCT) recipients. Infection 2012; 40: 271-278.

[15] Tumbarello M, Spanu T, Caira M, et al. Factors associated with mortality in bacteremic patients with hematologic malignancies. Diagn Microbiol Infect Dis. 2009; 64: 320-326.

[16] Conn JR, Catchpoole EM, Runnegar N, et al. Low rates of antibiotic resistance and infectious mortality in a cohort of high-risk 
hematology patients: A single center, retrospective analysis of bloodstream infection. PLoS One 2017; 12: e0178059.

[17] Miller PJ, Wenzel RP. Etiologic organisms as independent predictors of death and morbidity associated with bloodstream infections. J Infect Dis. 1987; 156: 471-477.
[18] Teh BW, Harrison SJ, Worth LJ, et al. Risks, severity and timing of infections in patients with multiple myeloma: a longitudinal cohort study in the era of immunomodulatory drug therapy. $\mathrm{Br} \mathrm{J}$ Haematol. 2015; 171: 100-108.

A cikk a Creative Commons Attribution 4.0 International License (https://creativecommons.org/licenses/by/4.0/) feltételei szerint publikált Open Access közlemény, melynek szellemében a cikk bármilyen médiumban szabadon felhasználható, megosztható és újraközölhető, feltéve, hogy az eredeti szerző és a közlés helye, illetve a CC License linkje és az esetlegesen végrehajtott módosítások feltüntetésre kerülnek. (SID_1) 